University of Texas Rio Grande Valley

ScholarWorks @ UTRGV

School of Social Work

2021

\title{
"No queremos quedar mal": A qualitative analysis of a boundary setting training among Latina community health workers.
}

Luis R. Alvarez-Hernandez

The University of Texas Rio Grande Valley, luis.alvarezhernandez@utrgv.edu

J. Maria Bermudez

Pamela Orpinas

Rebecca Matthew

Alejandra Calva

See next page for additional authors

Follow this and additional works at: https://scholarworks.utrgv.edu/sw_fac

Part of the Social Work Commons

\section{Recommended Citation}

Alvarez-Hernandez, L. R., Bermúdez, J. M., Orpinas, P., Matthew, R., Calva, A., \& Darbisi, C. (2021). “No queremos quedar mal": A qualitative analysis of a boundary setting training among Latina community health workers. Journal of Latinx Psychology, 9(4), 315-325. https://doi.org/10.1037/lat0000193

This Article is brought to you for free and open access by ScholarWorks @ UTRGV. It has been accepted for inclusion in School of Social Work by an authorized administrator of ScholarWorks @ UTRGV. For more information, please contact justin.white@utrgv.edu, william.flores01@utrgv.edu. 


\section{Authors}

Luis R. Alvarez-Hernandez, J. Maria Bermudez, Pamela Orpinas, Rebecca Matthew, Alejandra Calva, and Carolina Darbis 
Title: "No Queremos Quedar Mal”: A Qualitative Analysis of a Boundary Setting Training Among Latina Community Health Workers

\section{Authors:}

Luis R. Alvarez-Hernandez ${ }^{\text {a* }}$ - https://orcid.org/0000-0001-8695-5817

J. Maria Bermudez ${ }^{\mathrm{b}}$ - https://orcid.org/0000-0002-8482-4220

Pamela Orpinas ${ }^{\mathrm{c}}$ - https://orcid.org/0000-0001-9119-1954

Rebecca Matthew ${ }^{\mathrm{a}}$ - https://orcid.org/0000-0001-8144-5375

Alejandra Calva ${ }^{\text {a, c }}$ - https://orcid.org/0000-0002-2601-0165

Carolina Darbisi ${ }^{\mathrm{d}}$

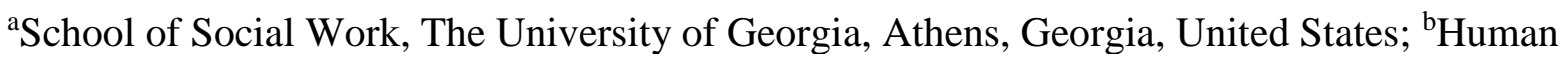
Development and Family Science, The University of Georgia, Athens, Georgia, United States; ${ }^{\mathrm{c} C o l l e g e}$ of Public Health, The University of Georgia, Athens, Georgia, United States; ${ }^{\mathrm{d} J}$.W. Fanning Institute for Leadership Development, The University of Georgia, Athens, Georgia, United States

*Corresponding author: lalvarez@uga.edu

Acknowledgments: We would like to acknowledge and thank the promotoras, founding members of Lazos Hispanos, for participating in this study and for their invaluable feedback in developing our training.

Declaration of interest statement: No potential conflict of interest was reported by the authors.

Funding details: This work was supported by the Office of the Vice President for Research, the Latin American \& Caribbean Studies Institute, and the School of Social Work at the University of Georgia, Athens, GA. The content is solely the responsibility of the authors and does not necessarily represent the official views of the university.

(C) American Psychological Association, 2021. This paper is not the copy of record and may not exactly replicate the authoritative document published in the APA journal. The final article is available, upon publication, at: Alvarez-Hernandez, L. R., Bermúdez, J. M., Orpinas, P., Matthew, R., Calva, A., \& Darbisi, C. (2021). "No queremos quedar mal": A qualitative analysis of a boundary setting training among Latina community health workers. Journal of Latinx Psychology, 9(4), 315-325. https://doi.org/10.1037/lat0000193 


\section{“No Queremos Quedar Mal": A Qualitative Analysis of a Boundary Setting Training Among Latina Community Health Workers}

Abstract: Community health workers — or promotoras de salud in Spanish—-have successfully addressed the health needs of Latinx and immigrant populations. However, for promotoras, setting boundaries is particularly difficult given challenges like residing in the same communities as their participants. The purpose of this study was to describe the development and impact of a boundary setting training to support the emotional well-being of immigrant promotoras. The training (four 1-hour sessions) was informed by social cognitive theory and a Chicana feminist framework. The promotoras who participated in the training helped create Lazos Hispanos, a community-based participatory research study and community health worker program located in the Southeastern United States. The goal of Lazos Hispanos is to increase access to health and social services among local Latinx community members. Five promotoras completed the training after one year of participating in the program. Thematic analysis was used to interpret findings from two semi-structured group interviews. Two themes emerged: (1) the promotoras negotiated gendered and cultural expectations when setting boundaries, and (2) they felt a stronger sense of personal and professional agency. Findings suggest that this boundary setting training had a positive effect on their sense of professionalism, emotional well-being, and ability to establish boundaries. They reported having less guilt and anxiety as they navigated gendered and culturally informed expectations. Similar trainings could be adapted to other immigrant and minoritized groups.

Spanish Version of Abstract: Las promotoras de salud han tenido éxito en abordar las necesidades de salud de las poblaciones Latinxs e inmigrantes. Sin embargo, para las promotoras, establecer límites es particularmente difícil debido a retos como vivir en las mismas 
comunidades que sus participantes. El propósito de este estudio fue describir el desarrollo e impacto de un adiestramiento acerca del establecimiento de límites para apoyar el bienestar emocional de promotoras inmigrantes. El programa (cuatro sesiones de una hora) fue informado por la teoría social cognitiva y un marco feminista de Chicanas. Las promotoras que participaron en el adiestramiento ayudaron a crear Lazos Hispanos, un estudio de investigación basado en participación comunitaria y programa de promotoras localizado en el sureste de los Estados Unidos. La meta de Lazos Hispanos es aumentar el acceso a servicios de salud y sociales entre miembros de la comunidad Latinx. Cinco promotoras completaron el adiestramiento después de un año participando en el programa. Un análisis temático fue utilizado para interpretar los hallazgos de dos entrevistas grupales semi-estructuradas. Dos temas emergieron: (1) las promotoras negociaron expectativas de género y culturales al establecer límites y (2) ellas sintieron una mejora en su sentido de agencia personal y profesional. Los hallazgos sugieren que el adiestramiento para establecer límites tuvo un efecto positivo en su sentido de profesionalismo, bienestar emocional y habilidad en establecer límites. Ellas reportaron sentirse menos culpables y ansiosas al navegar expectativas basadas en género y cultura. Adiestramientos similares podrían ser adaptados para otros grupos de inmigrantes y minoritarios.

Keywords: boundary setting, culturally informed training, promotoras de salud, Chicana feminism, stress

Public Significance Statement: Promotoras de salud often experience challenges when setting boundaries with participants. Gendered and cultural values and expectations often complicate this process. We developed a gender and culturally responsive training for establishing professional boundaries. The training resulted in enhanced emotional well-being among the 
promotoras as they learned to set limits, expectations, and goals early in the relationship with community participants. 


\section{Background}

Community health workers (CHWs) — or promotoras de salud in Spanish ${ }^{1}$ — have been successful in promoting health and well-being and reducing health disparities in Latinx (an all gender-inclusive term for Latino and Latina, which refer to men and women respectively) and immigrant communities (Nuño, Martinez, Harris, \& García, 2011; Rios-Ellis et al., 2015; Wilkinson-Lee et al., 2018). Promotoras de salud, or promotoras for short, are community leaders who provide peer support, education, and connection to necessary resources and services. Community participants often see promotoras as a source of emotional support due to their connection with their communities (Albarran, Heilemann, \& Koniak-Griffin, 2014), as friends and aquaintances. As such, promotoras can often experience challenges delineating boundaries between being a community member and acting in their professional role.

\section{Boundary Setting}

Setting boundaries with clients or participants is common in professional helping relationships (Herlihy \& Corey, 2015). Boundaries in therapeutic relationships are active rules that frame what and how things are done within a particular system (Langs, 1998). Boundaries in professional counseling, for example, are essential for setting ethical expectations of the clientcounselor relationship and serve as a tool for therapeutic change (Amis, 2017). How a person sets and maintains boundaries also provides mental health clinicians with information about how the client thinks and establishes relationships with others, including patterns formed in childhood (Brown \& Stobart, 2018). Boundaries in professional helping relationships are then vital for establishing an ethical working relationship, ensuring an effective helping process, and

\footnotetext{
${ }^{1}$ This study uses the female Spanish translation for community health workers, promotras de salud or promotoras, instead of the male version, promotores de salud or promotores, given that all participants in this study were Latina women.
} 
determining an intervention's outcomes (Barnett, 2015). Maintaining those boundaries in helping relationships is the responsibility of the service provider. As helping professionals, promotoras often find it difficult to enact this responsibility due to being members of the communities they serve.

For promotoras, setting boundaries can be particularly difficult given the challenges of navigating participants' schedules and meeting participants during non-business hours and at informal locations (e.g., participants' homes, local restaurants) (Manzo, Rangel, Flores, \& de la Torre, 2018). Promotoras often reside in the same communities as their participants, thus further challenging their ability to establish professional boundaries (Messias et al., 2013). Difficulties establishing and maintaining clear boundaries may lead to promotoras' stress and early burnout (Visión y Compromiso, 2014). A growing body of research examines the development and delivery of health-specific training to promotoras (e.g., Askari et al., 2018; Bustillos and Sharkey, 2015); however, research on setting boundaries for CHWs is scarce. To meet the need for a boundary setting training for Latina CHWs that is gender and culturally informed, the authors developed a training, provided it to Latina CHWs, and then explored the training's effectiveness.

\section{Conceptual Frameworks}

Social cognitive theory and Chicana feminism informed the development of the training and analysis of the findings. Social cognitive theory asserts that observations and cognitions influence a person's behavior (Bandura, 1986). More specifically, the current training considered the constructs related to personal cognitive factors (i.e., self-efficacy, outcome expectation, and knowledge), socio-environmental factors (i.e., observational learning, normative beliefs, social support, and barriers and opportunities), and behavioral factors (i.e., behavioral skills, intentions, 
and reinforcement) (Kelder, Hoelscher, \& Perry, 2015). For example, we conducted the training in a group format, which served as much-needed social support. The facilitators addressed the promotoras' difficulty managing multiple roles by increasing their knowledge about boundary setting and enhancing their confidence or self-efficacy in their abilities to set boundaries and communicate their CHW role to participants. This process was possible through engaging the promotoras in observational learning activities while also practicing various behavioral skills. The training also allowed the promotoras to discuss their own barriers in setting boundaries and set intentions for future interactions with participants. Moreover, due to the promotoras being concerned about doing a "good job" and not wanting to be "on bad terms with participants," the facilitators encouraged them to explore their normative beliefs about setting boundaries. It became apparent in the analysis that strong gendered and cultural norms and scripts informed their beliefs. Hence, we used Chicana feminism as a lens to understand this exploration.

Chicana feminism grew out of the need to interrupt oppressive male-female relationships sometimes present within Mexican-origin communities, specifically examining the ways in which traditional gendered roles can contribute to gender oppression (Lucero-Liu \& Christensen, 2009). Chicana feminism directly challenges patriarchy (Anzaldúa, 2012; Garcia, 1989; Hurtado, 1998b) and attends to intersectionality (i.e., multiple domains of identity and larger social forces). It encourages scholars to critically consider gendered and social class norms among people from Mexican origin (Lucero-Liu, \& Christensen, 2009). Moreover, traditional Latinx cultural values embrace these norms, such as familismo, personalismo, and gendered scripts for women, such as marianismo (e.g., Comas-Diaz \& Greene, 1994; Falicov, 2014). In the traditional Latinx cultures, these cultural and gendered related values intersect with boundary setting, as Latinas are often socialized to be self-sacrificing, yielding, and accommodating, which 
centralizes their roles as caretakers. For example, the promotoras have verbalized the need to balance participants' demands with family responsibilities (Orpinas, Matthew, Alvarez-

Hernandez, et al., 2020). They wanted to be caring and responsible yet felt bad when they had to say "no" or make time for themselves. Chicana feminism situates context, culture, and gender; therefore, it was a valuable lens to interpret these findings. Delgado-Romero, Singh, and De Los Santos (2018) have highlighted the importance of critical and intersectional qualitative research that considers language, culture, and community trust.

\section{Boundary Setting Training}

The current study discusses the development and preliminary outcomes of a boundary setting training for promotoras. The training was created as a response to their feedback, as they often commented on their interpersonal difficulties with participants due to their multiple roles, and the tensions they felt when not meeting the expectations of community participants. This difficulty in managing limits left them feeling frustrated, stressed, and anxious. The phrase repeatedly used by the promotoras in this study was "no queremos quedar mal," which roughly translates in English as "we don't want to disappoint." This phrase reflected their desire to do a good job when enacting their responsibilities as promotoras. Consequently, the current training was developed to improve their emotional well-being, address challenges navigating dual roles with participants, review and re-establish their role as a promotora, prevent burnout, and ensure ethical practice.

We identified the promotoras' difficulties with setting boundaries. We used this information to guide the development of this gender and culturally responsive training, which consisted of four, 1-hour sessions, delivered over three months. For example, we added a discussion on the Spanish-version of the "feelings wheel" (e.g., ira, tristeza, felicidad, miedo) 
when the promotoras said they were feeling bad (me siento mal) about setting boundaries. The themes of the four sessions were: (1) introduction to boundary setting, (2) boundary setting with participants and the roles of promotoras, (3) goal setting as a form of establishing firm boundaries, and (4) self-disclosure with participants (Table 1).

[Insert Table 1 approximately here]

Each session started with open-ended discussion questions, followed by experiential learning, group dynamics, and skill-building exercises. To discuss their ethical dilemmas, we used teaching tools like a SMART (i.e., specific, measurable, attainable, relevant, time-limited) worksheet for setting goals (O’Neill et al., 2009) and case examples and vignettes based on the promotoras' field experiences. This process enabled us to create iteratively a training that was gender and culturally responsive, reflective of the literature, and relevant to the promotoras' field experiences.

\section{Purpose of the Study}

Research studies on the impact of boundary setting in the work of promotoras are scarce, especially when considering the effects of culture and gender. In response to this gap, the current study explores the impact of a pilot training for boundary setting developed for Latina promotoras.

\section{Method}

\section{Participants}

The promotoras who participated in the training were members of Lazos Hispanos, a community-based participatory research (CBPR) study and CHW program located in the Southeastern United States. The goal of Lazos Hispanos is to increase access to health and social services among local Latinx community members. Latinx individuals in this community face 
multiple, interconnected barriers when trying to access health and social services (e.g., Calva, Matthew, \& Orpinas, 2020). Hence, the promotoras serve as a bridge, ambassadors, and connectors between the Latinx community and the service providers (Orpinas, Matthew, Bermúdez, et al., 2020). The strengths of the roles of CHW, in general, and of the promotoras of Lazos Hispanos, in particular, have been discussed elsewhere (Matthew et al., 2020). When the project started, nine promotoras joined Lazos Hispanos. However, due to family and work responsibilities, four promotoras left the program-leaving only five promotoras to partake in this training.

The five Spanish-speaking promotoras who participated in the current training were Mexican immigrants, married, and mothers. Their ages ranged between 35 and 44 years. Most were living in their communities for over a decade. All of them had been volunteering for one year with Lazos Hispanos.

Before completing the boundary setting training, the promotoras had already completed over 70 hours of training in the areas of "leadership, effective communication, empowerment, group dynamics, [and] conflict management." (Orpinas, Matthew, Bermúdez, et al., 2020, p. 2). These trainings were based on the skills recommended for community health workers at the national level (Rosenthal, Hush, \& Allen, 2016). The promotoras also received ongoing weekly individual check-ins and monthly group supervision and support from members of the research team with experience in social and mental health services. It was during these check-ins and supervision interactions that the promotoras reported difficulties with setting boundaries.

\section{Data Collection and Analysis}

As part of a comprehensive year-1 evaluation (Orpinas, Matthew, Bermúdez, et al., 2020), five promotoras participated in two, in-depth, semi-structured group interviews (one 
group composed of three, the other of two), following completion of the boundary setting training in the fall of 2018. The promotoras received research incentives on an ongoing basis for their participation in the CBPR project, including their involvement in these evaluation interviews. We explored their thoughts about the training, the effects it had on their emotional well-being, and the application of strategies in their role as promotoras. Each interview ranged between 1 and 2 hours, and both were transcribed verbatim in Spanish. The interviewers, notetakers, and data analysts were bilingual, bi-cultural Latinx researchers. The University's institutional review board approved all research procedures.

To examine the promotoras' experience with the boundary setting training, we followed the six steps of thematic analysis as delineated by Braun and Clarke (2006). First, the first two authors read the original transcripts in Spanish numerous times and conducted line-by-line coding, took notes, and mapped salient constructs. Second, a hierarchy of themes was created with sub-themes. Especially challenging was to see the themes as discrete, as many of the codes and themes were interconnected. Third, we examined similarities across participant's responses and formed them into groupings known as themes. We used an inductive approach to allow for greater inclusion of participant narratives and contextual factors, such as their lives as mothers, wives, immigrants, and employees. Fourth, after identifying initial themes, we re-read the quotations coded within each theme. We conceptualized the themes until both coders agreed with the final themes, and no other themes emerged. Fifth, we developed the final names for each theme. Sixth, verbatim quotations and excerpts were selected from the transcripts. Although the process is presented as phases, the process was recursive and non-linear.

During the thematic analysis process, the first two authors made meaning of the data through a Chicana feminism lens. In thematic analysis, a theoretically-driven constructionist 
analysis is possible as long as there is a clear connection between theory and findings (Braun \& Clarke, 2009). Therefore, following Chicana feminism, the authors linked participants' statements about their experiences as promotoras to gendered sociocultural scripts for Latina women.

To increase the trustworthiness of the findings, the first two authors read the transcripts several times and worked side-by-side to collaboratively code, analyze, and develop themes (Braun \& Clarke, 2006; Nowell, Norris, White, \& Moules, 2017). After completing the first summary of themes, three of the five promotoras were available to review the findings, verify the summary, and offer additional comments (Lincoln \& Guba, 1985).

\section{Researcher Positionality}

All six authors work together as researchers on the Lazos Hispanos team. Collectively, the authors are predominantly a group of bicultural, bilingual, and Latinx researchers at our University, with most of them being Latinas. The authors' professional backgrounds are in social work, public health, marriage and family therapy, and adult education. They are from Puerto Rico, Honduras, Chile, México, the United States, and Venezuela. Their experiences with migrating or moving into the United States vary in terms of privilege. In response to the tremendous need for Latinx people residing in low-income communities and needing access to community services, the team developed a culturally responsive, community-based participatory research project (Authors, 2020). The aim was to work closely with people already identified as Latinx leaders in the community to take the role as promotoras de salud, as well as with local agencies, clinics, and organizations to help better serve the Latinx community.

The authors embrace the tenets of emancipatory, decolonizing, intersectional, and feminist informed practices. As such, it became evident that the promotoras in the program were 
struggling with how to navigate the tension of setting and maintaining boundaries in their role. The authors identified this dynamic as consistent with the struggles many Latinas have due to constraining gendered and cultural scripts. Although most of the authors are professional women with power and societal influence, they also identified with these tensions of navigating personal and professional boundaries. By creating this training, the authors were also reminded of the need for their self-empowerment as Latinas.

The first and second authors worked collaboratively on the analysis of the interviews. The first author, a cisgender and gay Puerto Rican man, strived to recognize how his male privilege and college education influenced how he developed and delivered the training. He was also keenly aware of the larger systemic forces that shaped how he perceived and analyzed the training outcomes. For example, as a gay Latino, he is constantly navigating traditional cultural and gendered scripts. In this process, both the promotoras and the first author continuously resist the expectations of a society that often attempts to determine their roles and impose stereotypical values upon them. The second author is a Latina immigrant from Honduras, an associate professor, and a licensed marriage and family therapist. She identifies as a cisgender woman, heterosexual, and able-bodied. Her research centers on Latinx family resilience and feministinformed research and clinical practice. Even while holding many privileged identities, similarly to the promotoras, she constantly navigates the cultural and gendered expectations placed on her as a Latina, who often over commits and puts the needs of others at her expense.

\section{Results}

The promotoras found the training valuable and stated they effectively used it with participants and in personal relationships. From the interviews, two themes emerged: (1) negotiating gendered and cultural expectations with boundary setting, and (2) feeling a stronger 
sense of personal and professional agency. Quotes are in English, followed by the original quote in Spanish in parenthesis. Some information has been added in brackets to provide context for the quotes.

\section{Negotiated Gendered and Cultural Expectations When Setting Boundaries}

In the process of setting boundaries, the promotoras negotiated gendered and cultural values, such as familismo, personalismo, and marianismo. Although the promotoras did not specifically name these terms, it was evident to us as Latinx scholars using a Chicana feminism framework, that their experiences reflected these values. During the member checking process, the promotoras confirmed these findings. For instance, wanting to do a "good job" and not disappoint their participants (no queremos quedar mal) was a priority for the promotoras, and a consistent thread throughout the data. As with marianismo, the promotoras reflected that they had engaged in an emotional caretaking role to the point of self-sacrificing. They were concerned about how to say "no," often needing “permission to say no.” One promotora stated, "Once I dared to say the first 'I can't' it became easier [to continue saying it]." ("Una vez que me atreví a decir el primer "no puedo" se me hizo más fácil [seguir diciéndolo].”) Last, one promotora stated that it was easier for her to practice setting boundaries first with her family and then with participants.

The promotoras expressed strong feelings related to boundary setting. First, they commented how, before the training, setting boundaries with their participants made them feel guilty, stressed, and anxious. One promotora reflected on what could be described as the value of personalismo and confianza (trust) that led her to invite some participants into her home. Then, in another instance, a group of participants arrived at her house unannounced. This promotora blamed herself for not setting boundaries earlier on with participants. She shared, "For me, it was 
embarrassing because I encouraged them [by failing to establish boundaries]. I mean, for wanting to help, I got in trouble." ("Para mí me daba vergüenza, porque yo misma los provoqué [al no establecer límites]. O sea, yo misma, por el querer ayudar, me metí en problemas.”) The trouble she expressed was related to overcommitting and allowing strangers into her personal life. Second, when they shared this burden with the other promotoras, it helped them normalize it and responded accordingly. A promotora shared, "I think the embarrassment [of sharing problems with participants due to lack of boundaries] doesn't go away, but it does give you like a sense of relief." (Yo creo que la pena [de compartir los problemas con participantes por no establecer límites] no se quita, pero si te da como un "sense of relief.")

Setting boundaries was also about safety for cases that involved severe problems, like intimate partner violence. Regarding participants with family problems, a promotora stated: I have learned that I should not involve myself in those types of problems, like if it were my own family. I have to set my limit as a promotora and a limit as participant and promotora. Because maybe years ago, without the promotora training, I think I would have gone into their home to get the person out. (Y yo aprendí que no me debo involucrar en ese tipo de problemas como si fuera mi familia. Tengo que poner mi límite como promotora y mi límite como de participante y promotora. Porque hubiera sido tal vez con años atrás, sin tener el entrenamiento como promotora, yo creo que me hubiera metido hasta la casa para sacar a esa persona.)

This example reflects a sense of familismo. The promotoras stated that this action would have been appropriate if the people would have been their family. Still, given that they were not, it was not appropriate or within their scope of practice as promotoras. They gained clarity about 
how they needed to interact with participants differently than with their family and friends and not to give them more confianza (trust) than was warranted.

Through the process of integrating the information and skills learned during the training, the promotoras stated that they engaged in self-talk to remind themselves about the benefits of setting boundaries. They found a balance between being able to say "no," which defies their gender script as women, and being able to "no quedar mal" (not to disappoint), which is upholding the cultural value of personalismo. After engaging in this process, the promotoras saw boundary setting as "good, necessary, important, and freeing” ("bueno, necesario, importante y liberador") for their emotional well-being. The promotoras are now supporting participants while also valuing their own time and considering their own needs. They reported feeling more in control, calm, and relieved when gently, but firmly, setting boundaries with participants.

\section{Felt a Stronger Sense of Personal and Professional Agency}

The promotoras expressed that setting boundaries enhanced their sense of personal and professional agency. This sense of agency helped them set limits, expectations, and goals early in their relationships with participants. Additionally, the promotoras started to share the responsibility of boundary setting with the research team. For example, they would tell participants that they were unable to do something because their supervisors would not allow them to go outside of their role. Stating that their supervisors enforced boundaries helped free them from being portrayed negatively. They also found it easier to manage their time and set their schedules, which led them to feel more organized and in control. This organization enabled them to have more time for other activities, such as prioritizing time with family and community activism. 
Additionally, they became more assertive with their participants, as well as in their personal relationships. They stated that setting boundaries helped them become better mothers and even advocate for their children in school. They found themselves saying "no" more often and with more ease without feeling guilty. One promotora discussed that they were transporting participants in their own cars, even when this was beyond the scope of their responsibilities:

But us, like good Christians, we knew we had to give them. Then, the times that we didn't want to give rides, we felt bad. Then the [boundary setting] training was something that helped us to start. To not answer calls when it was late at night and to say "no" if you couldn't. And to not feel bad when you said "no" even when you could do what they asked. That helped us a lot. It was a very good, very good lesson.

(Pero nosotras como buen cristiano, sabíamos que teníamos que darlo entonces, alguna vez que no lo queríamos hacer, nos sentíamos mal. Entonces la charla [de establecer límites] fue algo que nos ayudó para empezar. Para no contestar llamadas cuando ya no eran horas y para decir "no”, si no podías. O, aunque pudieras, decías “no” pues sin sentirte mal. Entonces eso nos ayudó mucho. Esa fue una muy buena, muy buena lección.)

An unintentional outcome that emerged from the training was that promotoras improved their negotiation skills and encouraged participant empowerment. For example, they reported encouraging participants to first think about their own resources and to contact the promotora only if those resources did not work. They also learned that they could be clear and firm about boundaries while at the same time being flexible and not rigid in cases of emergencies. For example, one promotora stated, 
I had a participant who would call me at night. OK, I can answer a text at 7 in the evening. But then it's at 9, then 11. I said, they are not going to let me sleep because then it's going to be at 3 in the morning. I talked to the person, and I asked them to call during my office hours and that at 6 in the evening was fine. But she can call later, but it would be possible that I would not answer until the next day in the morning.

(Yo tenía un participante que a veces me llamaba en la noche. 7 de la tarde, okay, contestas un texto. Después 9, después las 11. Yo dije, no me va a dejar dormir, luego será a las 3 de la mañana. Yo hablé con esta persona y le dije que podría ser entre mis horas de oficina y que a las 6 de la tarde estaba bien. Pero ya más tarde lo podría hacer ella, pero no estaba segura que yo contestara hasta el siguiente día por la mañana.)

They learned to trust their judgment and ability to discern when immediate action was necessary or if something could wait until the next day. The same promotora said, "but if the message seemed serious, then I would answer at that moment." (Si el mensaje lo veía como muy grave lo contestaría en ese momento.)

\section{Discussion}

With the increased demand for and professionalization of community health workers (CHWs), the development of boundary setting skills is an area in need of additional research (Malcarney, Pittman, Quigley, Horton, \& Seiler, 2017). The current study attends to this gap by describing a boundary setting training for promotoras and its preliminary outcomes. Guided by social cognitive theory and Chicana feminism, this training addressed the promotoras' 
difficulties with managing their feelings of guilt and anxiety related to meeting the expectations of participants and enhanced their agency to set appropriate boundaries.

The promotoras initially shared how the fear of disappointing their participants was an expected outcome of setting boundaries, primarily impacted by their cultural and gendered normative beliefs. Hence, expanding their own understanding of gendered and cultural socialization as Mexican immigrant women was informative and empowering. This process reduced self-blame and connected their experiences to larger sociocultural forces (Falicov, 2014; Lucero-Liu \& Christensen, 2009). Although they valued traits associated with traditional gendered roles, the promotoras also expressed feeling freed from the constraints of self-silencing and denying their own needs. This new expected outcome after setting boundaries was based on the promotoras enhanced self-efficacy about setting boundaries and clearer outcome expectations about their professional and personal roles (Bandura, 1986). Similar to the findings of Squires and O'Brien (2012), the promotoras reported that the training was transformative, as these skills helped them feel a stronger emotional and interpersonal well-being and to manage the complex role of being a CHW. Tran and colleagues (2014) also found a similar association between knowledge and emotional well-being after training promotoras on how to help other Latina immigrants cope with stress, depression, and anxiety.

Based on the findings, it was apparent that the training served to strengthen the emotional well-being of the promotoras. Through the examples the promotoras provided in the interviews, it became evident in this analysis that they improved their self-efficacy for setting limits. The promotoras stated that they became more confident in balancing their participants' needs with their own, gently setting firm boundaries with participants, being assertive about their needs and 
limits by saying "no," and negotiating others' expectations. Self-efficacy is a critical construct in successful health promotion programs (e.g., Harris-Luna \& Badr, 2018).

The promotoras stated that setting boundaries with their families first, served as a safe way of practicing the skills. Although not all persons may feel this safety within their own families, these women reported that their families were supportive and provided safe spaces for them to grow and learn as promotoras. Guided practice in a safe environment is a valuable strategy to increase self-efficacy (Bandura, 1986). Their self-efficacy was also evident in their report of an enhanced sense of personal and professional agency and control.

The training also helped them be more intentional with setting limits, which was initially challenging given that most were not taught to be assertive (gendered socialization) or to state their needs clearly (cultural socialization). By learning how to set limits and boundaries, they reported that they benefited by learning how to establish their own schedules, discern what to prioritize, have more time for family and community activism, and take better care of themselves. Also supported by social cognitive theory, modeling successful strategies and rehearsing how to overcome challenges with the other promotoras and the research team was fundamental in the learning process.

\section{Limitations and Strengths}

This study has some limitations. All the promotoras in the Lazos Hispanos program were volunteers. From the original nine promotoras who started the program, four left to pursue paid work or care for a family member. Hence, the sample was constrained to the five promotoras who remained in the program after the first year. The four promotoras who left the program did not have the opportunity to be part of the boundary-setting training. 
The time it takes to develop, practice, and maintain boundary-setting skills could be a potential limitation. Some promotoras may need additional time to practice the skills learned in the training. Additionally, it was difficult to isolate the effects of the boundary-setting training from other educational activities that the promotoras attended during the first year of the program (e.g., leadership training, interpersonal violence, and crisis response). Nevertheless, it was apparent that the promotoras demonstrated a clear before-and-after effect from the training, as they showed the ability to express their expectations in a clear, direct, and kind manner, without feeling guilty or worried about doing so.

Another dynamic was that a cisgender Latino man (first author) created most of the training content and delivered it. However, the Latina team members were vigilant about how his gender and power influenced the process (e.g., revising training materials beforehand, being present and active during the training, and debriefing and triangulating information after the training). Lastly, group interviews may have also affected the responses by increasing possible social desirability. Conversely, the group interviews led to rich dialogue and self-exploration.

Additionally, it is plausible that the promotoras could have inflated the training's positive effects not to disappoint or offend the research team (no quedar mal). However, during the group check-ins and group time for supervision and support during the following year, they consistently reflected on their continued use of the skills learned in the training. They repeatedly provided specific examples of how the boundary setting training was helpful to them personally and professionally. They continued to use the skills as they navigate the challenges associated with their roles (Authors, 2020).

This study also has noteworthy strengths. This study exemplifies the value of (1) incorporating boundary-setting training for community health workers, particularly immigrant 
Latina promotoras, and (2) developing a gender and culturally informed training using wellestablished theoretical frameworks. The study highlights how normative gendered and cultural beliefs impact the professionalization of community health workers $(\mathrm{CHW})$ and highlights strategies to improve knowledge, self-efficacy, and emotional well-being. Most relevant to all CHWs, this training could be adapted to other immigrant health workers, especially those from communal, collectivistic, and patriarchal cultures.

More research is needed to explore the effects of this training with CHWs from diverse populations and with specific boundary setting topics. Future research should also explore how CHWs navigate setting boundaries with people from other groups beyond their participants, including members of the research team, directors of agencies and clinics, service providers, and government leaders. In addition to examining the effects of this training across contexts, it could also be beneficial to investigate its effects over time. In sum, we contend that as the community health worker model continues to gain prominence, the standards for professionalization will likewise increase. Having a culturally and gender-informed training will be essential in supporting promotoras to feel empowered to set personal and professional boundaries and to achieve a healthy balance in managing their multiple roles. 


\section{References}

Albarran, C. R., Heilemann, M. V., \& Koniak-Griffin, D. (2014). Promotoras as facilitators of change: Latinas' perspectives after participating in a lifestyle behaviour intervention program. Journal of Advanced Nursing, 70(10), 2303-2313. https://doi.org/10.1111/jan.12383

Amis, K. (2017). Boundaries, power and ethical responsibility in counselling and psychotherapy. Sage.

Anzaldúa, G. (2012). Borderlands/La Frontera: the new mestiza (4th ed.). San Francisco, CA: Aunt Lute Books.

Askari, N., Bilbrey, A. C., Garcia Ruiz, I., Humber, M. B., \& Gallagher-Thompson, D. (2018). Dementia awareness campaign in the Latino community: a novel community engagement pilot training program with promotoras. Clinical Gerontologist, 41(3), 200-208. https://doi.org/10.1080/07317115.2017.1398799

Bandura, A. (1986). Social foundations of thought and action. Englewood Cliffs, NJ: Prentice Hall.

Barnett, J. E. (2015). A practical ethics approach to boundaries and multiple relationships in psychotherapy. Psychotherapy Section Review, 56, 27-35. http://www.societyforpsychotherapy.org/boundaries-and-multiple-relationships-inpsychotherapy-recommendations-for-ethical-practice

Braun, V., \& Clarke, V. (2006). Using thematic analysis in psychology. Qualitative Research in Psychology, 3(2), 77-101. http://dx.doi.org/10.1191/1478088706qp063oa

Brown, R., \& Stobart, K. (2018). Understanding boundaries and containment in clinical practice. Routledge. 
Bustillos, B. D., \& Sharkey, J. R. (2015). Development and implementation of a culturally and linguistically centered nutrition education program for promotoras de salud (community health workers) to foster community health education and outreach in Texas border colonias. Journal of Hunger \& Environmental Nutrition, 10(3), 299-312. https://doi.org/10.1080/19320248.2015.1007260

Calva, A., Matthew, R. A., \& Orpinas, P. (2020). Overcoming barriers: Practical strategies to assess Latinos living in low-income communities. Health Promotion Practice, 21(3), 355-362. https://doi.org/10.1177/1524839919837975

Comas-Diaz, L., \& Greene, B. (1994). Women of color: Integrating ethnic and gender identities in psychotherapy. New York, NY: The Guilford Press.

Delgado-Romero, E. A., Singh, A. A., \& De Los Santos, J. (2018). Cuéntame: The promise of qualitative research with Latinx populations. Journal of Latina/o Psychology, 6(4), 318328. https://doi.org/10.1037/lat0000123

Falicov, C.J. (2014). Latino families in therapy. (2nd ed.). New York: The Guilford Press.

Harris-Luna, M. L., \& Badr, L. K. (2018). Pragmatic trial to evaluate the effect of a promotora telephone intervention on the duration of breastfeeding. Journal of Obstetric, Gynecologic \& Neonatal Nursing, 47(6), 738-748.

https://doi.org/10.1016/j.jogn.2018.09.001

Herlihy, B., \& Corey, G. (2015). Boundary issues in counseling: Multiple roles and responsibilities [3rd ed.]. Alexandria, VA: American Counseling Association.

Kelder, S. H., Hoelscher, D., \& Perry, C. L. (2015). How individuals, environments, and health behaviors interact: social cognitive theory. In Glanz, K, Rimer, B. K., \& Viswanath, K. 
(Eds.), Health behavior: Theory, research, and practice (5th ed., pp. 159-181). San Francisco, CA: Jossey-Bass.

Langs, R. (1998). Ground rules in psychotherapy and counselling. Routledge.

Lincoln, Y. S., \& Guba, E. (1985). Naturalistic inquiry. Beverly Hills, CA: SAGE.

Lucero-Liu, A. A., \& Christensen, D. H. (2009). (Re) Visioning intimate relationships: Chicanas in family studies. In S. A. Lloyd, A. L. Few, \& K. R. Allen (Eds.), Handbook offeminist family studies (pp. 96-107). Thousand Oaks, CA: Sage.

Malcarney, M., Pittman, P., Quigley, L., Horton, K., \& Seiler, N. (2017). The changing roles of community health workers. Health Services Research, 52(1), 360-382. https://doi.org/10.1111/1475-6773.12657

Manzo, R. D., Rangel, M. I., Flores, Y. G., \& de la Torre, A. (2018). A community cultural wealth model to train promotoras as data collectors. Health Promotion Practice, 19(3), 341-348. https://doi.org/10.1177/1524839917703980

Messias, D. K. H., Parra-Medina, D., Sharpe, P. A., Treviño, L., Koskan, A. M., \& MoralesCampos, D. (2013). Promotoras de salud: roles, responsibilities, and contributions in a multisite community-based randomized controlled trial. Hispanic Health Care International, 11(2), 62-71. https://doi.org/10.1891/1540-4153.11.2.62

Matthew, R. A., Orpinas, P., Calva, A., Bermúdez, J. M., \& Darbisi, C. (2020). Lazos Hispanos: Promising strategies and lessons learned in the development of a multisystem, community-based promotoras program. The Journal of Primary Prevention, 41(3), 229243. https://doi.org/10.1007/s10935-020-00587-z 
Nowell, L. S., Norris, J. M., White, D. E., \& Moules, N. J. (2017). Thematic analysis: striving to meet the trustworthiness criteria. International Journal of Qualitative Methods, 16(1), 113. https://doi.org/10.1177/1609406917733847

Nuño, T., Martinez, M. E., Harris, R., \& García, F. (2011). A Promotora-administered group education intervention to promote breast and cervical cancer screening in a rural community along the U.S.-Mexico border: a randomized controlled trial. Cancer Causes and Control, 22(3), 367-374. https://doi.org/10.1007/s10552-010-9705-4

O’Neill, J., Conzemius, A., Commodore, C., \& Pulsfus, C. (2009). The power of SMART goals: Using goals to improve student learning. Solution Tree Press.

Orpinas, P., Matthew, R. A., Alvarez-Hernandez, L. R., Calva, A., \& Bermúdez, J. M. (2020). Promotoras voice their challenges in fulfilling their role as community health workers. Health Promotion Practice, 1-10. https://doi.org/10.1177/1524839920921189

Orpinas, P., Matthew, R. A., Bermúdez, J. M., Alvarez-Hernandez, L. R., \& Calva, A. (2020). A multistakeholder evaluation of Lazos Hispanos: An application of a community-based participatory research conceptual model. Journal of Community Psychology 48(2), 464481. https://doi.org/10.1002/jcop.22274

Rios-Ellis, B., Becker, D., Espinoza, L., Nguyen-Rodriguez, S., Diaz, G., Carricchi, A., Galvez, G, \& Garcia, M. (2015). Evaluation of a community health worker intervention to reduce HIV/AIDS stigma and increase HIV testing among underserved Latinos in the southwestern U.S. Public Health Reports, 130(5), 458-467. https://doi.org/10.1177/003335491513000509 
Rosenthal, E. L., Hush, C. H., \& Allen, C. G. (2016). Understanding scope and competencies: A contemporary look at the United States community health worker field. Retrieved from http://www.chwcentral.org/sites/default/files/CHW\%20C3\%20Project.pdf

Squires, A., \& O’Brien, M. J. (2012). Becoming a promotora: a transformative process for female community health workers. Hispanic Journal of Behavioral Sciences, 34(3) 457473. https://doi.org/10.1177/0739986312445567

Tran, A. N., Ornelas, I. J., Perez, G., Green, M., Lyn, M. J., \& Corbie-Smith, G. (2014). Evaluation of Amigas Latinas Motivando el Alma (ALMA): A pilot promotora intervention focused on stress and coping among immigrant Latinas. Journal of Immigrant and Minority Health, 16, 280-289. https://doi.org/10.1007/s10903-012-9735-y

Visión y Compromiso. (2014). A survey of promotores training programs in California 20122013. Retrieved from: http://visionycompromiso.org/wp_new/wpcontent/uploads/2016/08/survey_report_2015revise.pdf

Wilkinson-Lee, A., Armenta, A. M., Leybas Nuño, V., Moore-Monroy, M., Hopkins, A., and Garcia, F. A. R. (2018). Engaging promotora-led community-based participatory research: An introduction to a crossover design focusing on reproductive and mental health needs of a Latina community. Journal of Latina/o Psychology, 6(4), 291-303. https://doi.org/10.1037/lat0000119 


\section{Table 1}

Summary of the Boundary Setting Training

\section{Session 1 - Introduction to boundary setting}

Objectives: The promotoras will:

1. Identify characteristics of setting boundaries [health knowledge]

2. Identify gender and cultural expectations about setting boundaries [e.g., health knowledge, outcome expectations]

3. Strengthen their confidence in their ability to communicate their CHW roles to participants [e.g., self-efficacy] Activities:

Discuss characteristics of boundary setting

Create posters that define their roles as $\mathrm{CHWs}$

Practice a concise speech about their roles as $\mathrm{CHWs}$

Session 2 - Boundary setting and the roles of CHWs

Objectives: The promotoras will:

4. Differentiate between professional and personal roles [e.g., health knowledge]

5. Identify ethical dilemmas in setting boundaries [e.g., self-efficacy]

\section{Activities:}

List roles that apply and do not apply to CHWs

Practice strategies to set boundaries using vignettes that portray ethical dilemmas

Session 3 - Goal setting as a form of establishing boundaries

Objectives: The promotoras will:

6. Identify barriers for setting boundaries [e.g., normative beliefs, environmental facilitation, and barriers]

7. Enhance confidence in their ability to set boundaries [e.g., self-efficacy]

Activities:

Discuss experiences and challenges establishing boundaries

Complete the SMART Goals worksheet for addressing the needs of participants in a structured manner

List practical strategies for setting boundaries [e.g., set availability schedules, say "no," use of validation and referrals]

Session 4 - Self-disclosure with participants

Objective: The promotoras will:

8. Strengthen confidence in their ability to self-disclose appropriately when working with participants [e.g., self-efficacy] Activities:

Discuss experiences and challenges with self-disclosure

Enhance emotional literacy using the "feelings wheel"

Practice professional self-disclosure strategies [e.g., generalize their experiences, limit the amount of information disclosed] 